\title{
O Céu dos sábios: O sol de Platão a partir das estrelas DE NIETZSCHE
}

\author{
Marco Sabatini ${ }^{1}$
}

\begin{abstract}
Resumo: Muitos pensadores refletiram sobre os astros celestiais. Com Platão e Nietzsche, eles assumem uma posição alegórica intimamente relacionada com suas filosofias. Em $A$ República, o sol representa a verdade, por um lado, tornando-se o símbolo que movimenta o sábio por sua busca pelo conhecimento; por outro lado, representa também aspectos importantes da teoria política e epistemológica da filosofia platônica. Milênios depois, Nietzsche critica intensamente Platáo, diagnosticando aspectos dogmáticos em seu pensamento. Contra isso, as estrelas nietzschianas assumem um céu diversificado, cujos astros representam uma incrível variedade moral existente entre os seres humanos. Mas o filósofo moderno não se contrapóe à filosofia platônica simples e plenamente. Pretende-se demonstrar, com isso, que o sol de Platão e as estrelas nietzschianas servem como alegorias para sintetizar pontos fundamentais da concepção filosófica de tais pensadores; mas auxiliam também a evidenciar a complexidade existente na interpretação de Nietzsche sobre a filosofia platônica.
\end{abstract}

Palavras-Chave: Verdade. Dogmatismo. Política. Moral. Diversidade.

\section{INTRODUÇÃo}

Em todas as sociedades, o céu e os astros celestiais possuem uma ampla dimensão interpretativa e uma intensa importância cultural. Seja nas alturas daqueles deuses “[...] habitantes do palácio Olímpio" (HESÍODO, 2011, v. 963) da mitologia grega, seja lá “[...] onde se pode o que se quer" (DANTE, 1998, Canto III, v. 95) da concepção cristâ, seja nas diversas mitologias da África e da América do Sul, eles sempre se relacionam com o divino direta ou

\footnotetext{
${ }^{1}$ Pós-doutorando no Programa de Pós-Graduação em Educação da Universidade Federal de São Paulo (Unifesp), Guarulhos, SP - Brasil. (D) https://orcid.org/0000-0003-4757-3220. E-mail: marco_ rsabatini@hotmail.com.
}

https://doi.org/10.1590/0101-3173.2021.v44n2.17.p233

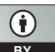

This is an open-access article distributed under the terms of the Creative Commons Attribution License. 
indiretamente. Na história da filosofia, o céu e os astros não causaram menor admiração e espanto. Tales de Mileto, um dos sete sábios da antiguidade de acordo com Platão, em Protágoras (2002, 343a), nutriu grande curiosidade no que pairava sobre os seus olhos. Conforme inúmeros relatos, ele predisse eclipses solares (inclusive, utilizando tal conhecimento associado ao comércio e às navegaçóes) e teria determinado os solstícios, além de declarar o tamanho do sol, identificar as estaçóes do ano e dividi-lo em 365 dias, descobrir a Ursa Menor etc. Entre os fragmentos reunidos por Hermann Diels (1901, p. 189), em Poetarum Philosophorum Fragmenta, consta a afirmação de Tímon sobre Tales de que ele fora um "sábio astrônomo entre os sábios".

Apesar de a veracidade dessas histórias ser constatada ou náo, talvez, o relato mais difundido sobre a vida de Tales não esteja relacionado com suas descobertas astronômicas, mas, sim, com sua famosa queda, enquanto contemplava o céu e refletia sobre ele. Entre as narrativas da antiguidade, dizia-se que,

[...] quando era levado para fora de casa por uma velha serviçal para observar as estrelas, Tales caiu numa vala, e seu grito de socorro levou a velha dizer: 'Como pretende, Tales, tu, que não pode sequer ver o que está à tua frente, conhecer tudo acerca do céu?' (LAÊRTIOS, 2008, p. 21).

Também Platão relatou esse caso em Teeteto (2015, 174a). A vasta sabedoria do filósofo sobre o universo parece, conforme o comentário feito por sua serva, incompatível com a atenção dada ao cotidiano, demonstrando a distância entre o conhecimento reflexivo e nossas necessidades práticas e diárias. Essa passagem - disseminada como uma mera piada para com os filósofos - não é tão simples assim e poderia ser interpretada com base em inúmeras perspectivas. No entanto, antes de tudo, ela revela uma sutil, porém complexa, relação entre a filosofia e a nossa vida cotidiana. Uma interpretação famosa diria que estamos presos a hábitos e necessidades corporais e que nossa preocupação se desviaria comumente da sabedoria. Daríamos, desse modo, mais atenção ao que é supérfluo e fugaz do que aos mistérios que nos cercam e nos constituem.

Essa interpretação é uma análise moral, se não criada, ao menos, coroada por Platão. Advinda de casos semelhantes ao de Tales de Mileto, ela se estende por todas as relaçóes da antiguidade que evidenciavam a desarmonia entre os sábios e os desejos gerais da pólis. Na filosofia platônica, Sócrates é o maior exemplo disso. Náo apenas como personagem de Platáo, ele assume também, 
enquanto representante histórico dos filósofos, uma posição de combate constante contra a ignorância que assolava Atenas. Arauto da sabedoria, abriu várias frentes de batalha. Elegendo os sofistas como seus grandes inimigos, Platão e seu Sócrates procuravam evidenciar, em Sofista (1972b, 264d), a "arte da falsidade", nascida a partir da intenção de produzir o "discurso falso" e a "opiniāo falsa”. Contudo, eles evidenciavam, também, a hipocrisia ateniense. Os ignorantes não ignoravam simplesmente seu desconhecimento, como se a não percepçáo de si pudesse legitimar suas condutas contrárias à sabedoria. Embora não classificassem suas opinióes como "ignorância", sabiam da dissonância entre as propostas socráticas e suas vontades políticas; mas as disfarçavam. Nesse sentido, a condenação de Sócrates não surgira para salvaguardar os jovens e os costumes atenienses de sua influência, como afirmaram os acusadores Meleto, Ânito e Licão, conforme se lê na Defesa de Sócrates (PLATÃO, 1972a, 23d), todavia, para consumar "[...] a calúnia e o rancor de tanta gente" (1972a, 28a).

Foi a partir desse caso que Platão interpretou o fardo e o ofício do filósofo: um ser direta e intimamente relacionado com a verdade. Em sua famosa alegoria escrita em $A$ república, a verdade é retratada na figura do sol, quando contemplada parcialmente pelo ex-prisioneiro que sai da caverna. Mais uma vez, o céu e os astros ganharam um significado filosófico, apesar de ser, nesse caso, alegórico. O sol representa um conhecimento imutável e dificilmente alcançável, acima das inúmeras opinióes que percorrem a cidade e a constituem politicamente. Desse modo, Platão atingiu dois alvos com um único golpe: por um lado, defendeu o seu mestre como um sábio injustiçado pela ignorância; por outro, exemplificou e eternizou tanto sua epistemologia quanto sua teoria política, baseadas em sua concepção metafísica sobre a realidade. Milênios depois, Nietzsche reinterpreta Sócrates e Platão, acusando-os de formular uma filosofia dogmática que ameaça a diversidade moral da existência humana, conforme afirmou ainda bastante jovem, em sua Einführung in das Studium der platonischen Dialoge (Segunda parte, \$11),

A exigência de formar conceitos exatos de todas as coisas parecia inofensiva: mas a filosofia, que crê tê-los encontrado, trata todos os outros homens como loucos e depravados e todas suas instituiçóes como loucuras e obstáculos ao pensamento verdadeiro. O homem ao conceito exato quer julgar e reger: crer possuir a verdade torna fanático. Esta filosofia é parte do desprezo da realidade efetiva dos homens: mais veloz, ela manifesta uma tendência tirânica. 
Nessa perspectiva, Nietzsche fixa solidamente sua crítica à filosofia platônica. Enquanto a censura a Tales era feita em funçáo do distanciamento entre seu conhecimento e a realidade que o cercava, Platão assume essa distância: o filósofo não se iguala ao indivíduo comum, justamente devido à sua busca pela verdade. Para a filosofia nietzschiana, tal posicionamento demonstra uma tendência tirânica em relação ao conhecimento que beira o fanatismo, pois, apesar do distanciamento específico do filósofo em relação à política e ao cotidiano, seus argumentos passam, no decorrer dos séculos, a constituir as estruturas políticas e conceituais da cidade, classificando o que diverge dele como "falsidade", "opinião", "erro", "ignorância”. O sol surge como uma verdade, única e eterna, contra as opiniốes advindas e baseadas nas necessidades imediatas das sensaçôes corporais. Entretanto, as perguntas que podemos aferir, a partir da filosofia de Nietzsche, são: o que a alegoria platônica esconde? Ela possui alguma semelhança com aquilo que critica? De qualquer modo, independentemente das perguntas e respostas sobre as quais possamos refletir, uma coisa é certa: a interpretação sobre o céu e sobre os astros se desloca, quando comparamos os pensamentos platônico e nietzschiano. Não mais entre a filosofia e sensocomum surge a peleja, mas, sim, entre os próprios filósofos.

\section{Filosofia NiETZSChiANA: “UM PLATONISMO INVERTIDo”?}

Antes de tudo, precisamos fazer uma ressalva. Como sabemos, um dos pontos mais fundamentais e polêmicos na filosofia de Nietzsche reside em sua crítica a Platão. De acordo com o filósofo, Platão lançou e consolidou as bases do cristianismo, muito antes dos pensadores medievais. Por meio de sua metafísica, o platonismo teria realizado uma verdadeira apologia a um plano ideal e radicalmente superior ao nosso mundo sensível. Ao corpo e a toda realidade material, restaria a insígnia do negativo, de sorte que o julgamento racional sobre a vida humana revelaria apenas seu caráter fugaz e errôneo. A partir dessa consideraçáo, o cristianismo teria legitimado sua prática de condenar os impulsos mais naturais do corpo humano, difundindo o medo e o gregarismo, entre seus fiéis. Sem nenhum dos resquícios nobres de Platáo², o pudor, a vingança, o ressentimento e a culpa seriam a expressão cristã de

\footnotetext{
${ }^{2}$ Em toda sua obra, Nietzsche expressa certa ambiguidade em relação a Platão: ele fora, indubitavelmente, corrompido por seu mestre plebeu Sócrates, porém se esforçou ao máximo para conservar sua nobreza. "Há algo na moral de Platâo que nâo pertence a sua filosofia e que por caprichos do acaso se encontra nela. Falamos do socratismo, que no fundo era repelido por sua natureza de aristocrata. [...] Platáo envidou todos os esforços para introduzir uma interpretação sutil e refinada da doutrina de seu mestre autor de qualquer outro motivo para introduzir a si mesmo, ele, o mais audaz dos intérpretes que
} 
corpos doentes e impossibilitados de expressar sua força vital. Nesse sentido, Nietzsche (BM, Prólogo) ${ }^{3}$ afirma em Além de bem e mal que "[...] cristianismo é platonismo para o 'povo'”.

Já em 1870, escrevia (KSA 7: FP-1870, 7[156]): “Minha filosofia, um platonismo invertido: quanto mais afastado do ser verdadeiro, tão mais puro e belo ele é. A vida na aparência como meta”. Esse aforismo condensa uma posição radicalmente oposta ao platonismo, levando a crer, muitas vezes, que os pontos de sintonia entre o pensamento nietzschiano e Platão seriam ou inexistentes ou absolutamente contrários, em suas argumentaçóes. Nietzsche narraria, assim, "[...] a história do erro mais longo" (LÖWITH, 1991, p. 121), deixando evidente sua posição contrária à filosofia socrático-platônica desde $O$ nascimento da tragédia, onde demonstraria que, "[...] com Sócrates, a época da tragédia chega a seu término, e começa a época da razão e do homem teórico" (FINK, 1965, p. 35). No entanto, a perspectiva de uma filosofia invertida simplifica demais as relaçóes entre tais pensadores. De acordo com Paschoal (1999, p. 47), Nietzsche “[...] afirma que um filósofo deve dispensar atenção ao espírito de seus leitores, não podendo, por exemplo, utilizar um conceito que não tenha sido, primeiramente compreendido". Isso significa que o filósofo deve se impor uma rigorosidade precisa ao publicar suas ideias; algo que não era exigido quando Nietzsche anotava seus pensamentos apenas para $\mathrm{si}^{4}$.

Apesar da aparente oposição inicial entre a tragédia e a tendência socrática, o filósofo nunca supôs nenhuma era cujas forças foram unificadas; ou melhor, nunca supôs uma época que não tenha sido diversificada e contraditória, tanto em relação às suas sociedades quanto aos seus indivíduos. Mesmo as personagens que aparecem em seu pensamento são (con)fusóes e tensóes de forças. Sócrates foi, por exemplo, um emaranhado de pulsões,

apanhou nas ruas todo o Sócrates como um tema ou canção popular para fazer variações até o infinito e impossível; ou seja, em todas suas próprias máscaras e multiplicidades” (BM, \$190).

3 As citaçôes das obras de Nietzsche serão feitas pelas siglas padronizadas pela pesquisa nacional e internacional; em seguida, o capítulo/aforismo. Para as anotaçôes não publicadas, adotamos a edição crítica das obras completas: Sämtliche Werke. Kritische Studienausgabe (KSA). Para as demais obras, segue: Introdução à tragédia de Sófocles (ITS); Introdução aos estudos dos diálogos platônicos (IDP); Sócrates e a tragédia (ST); O nascimento da tragédia (NT); Humano, demasiado Humano I (HH); Aurora (A); Assim falou Zaratustra (ZA); Além de bem e mal (BM); Crepuisculo dos ídolos (CI).

${ }^{4}$ Ainda segundo Paschoal (1999, p. 48), “[...] a utilização do caráter hipotético nas obras publicadas significa, também, que ele se previne diante da possibilidade de que os textos sejam entendidos como sistemas. Esse cuidado é ainda mais acentuado se nessas obras se encontra a expressão 'vontade de poder', que pode ser tomada como princípio metafísico. Para afastar esse tipo de perigo, Nietzsche lança mão do que Stegmaier denomina de 'princípio delimitativo', um cuidado que ele náo precisa ter quando anota para si”. 
a ponto de Nietzsche tornar ainda mais complexa a relação entre o filósofo antigo e a arte. Em $O$ nascimento da tragédia, Nietzsche (NT, \$14) perguntase "[...] se de fato existe necessariamente, entre o socratismo e a arte, apenas uma relação antipódica e se o nascimento de um 'Sócrates artístico' não é em si algo absolutamente contraditório". Essa reflexão nietzschiana surge de uma breve passagem do diálogo Fédon (60e), no qual o filósofo, preso e aguardando a consumação de sua pena, confessa a seus ouvintes: "[...] muitas e muitas vezes em minha vida pregressa, sob formas diferentes me apareceu um sonho, sempre dizendo a mesma coisa: 'Sócrates', me falava, 'compóe música e a executa”. A partir disso, Nietzsche (NT, \$14) ressalta:

Aquele lógico despótico tinha, cumpre afirmar, aqui e ali, com respeito à arte, o sentimento de uma lacuna, de um vazio, de meia censura, de um dever talvez negligenciado. Com frequência vinha-lhe, como na prisão contou a seus amigos, uma e a mesma aparição em sonho, que sempre lhe dizia o mesmo: "Sócrates, faz música!". Ele se tranquiliza, até os seus últimos dias, com a opiniáo de que o seu filosofar é a mais elevada arte das Musas, e não acredita plenamente que uma divindade venha lembrá-lo daquela "música popular, ordinária". Por fim, na prisão, para aliviar de toda a sua consciência, dispóe-se a praticar também aquela música por ele tấo menosprezada.

Não existe, desse modo, uma relação simplista de oposição e negação entre Sócrates e a arte para Nietzsche. Também os trágicos fizeram parte da tendência racionalista ${ }^{5}$ que pairava sobre a Grécia antiga ${ }^{6}$. De acordo

5 É importante ressaltar que a tendência racionalista da Grécia clássica foi a expressão de diversos pensadores como Tales, Parmênides, Eurípides, provando “[...] que eles próprios, esses mais sábios dos homens, em alguma coisa coincidiam fisiologicamente, para situar-se - ter de situar-se - negativamente perante a vida” (CI, O problema de Sócrates, \$2). Essa tendência se exprimiu plenamente em Sócrates. Contudo, "[...] o socratismo é mais antigo que Sócrates" (ST). Ou seja, a interpretação nietzschiana percebeu o socratismo apenas como um sublime exemplo dessa lógica. "O elemento da dialética, peculiar dele, se introduziu”, por exemplo, "[...] furtivamente no drama musical já muito tempo antes de Sócrates, e produziu em seu belo corpo um efeito devastador” (ST).

${ }^{6} \mathrm{Em} O$ nascimento da tragédia, é interessante notarmos que Sófocles é uma espécie de intermediário entre Ésquilo (mais próximo dos coros primitivos dionisíacos) e Eurípides (distante dos primórdios da tragédia e próximo ao racionalismo socrático). Apesar de suas tragédias não eliminarem plenamente o elemento dionisíaco, "[...] aquele deslocamento da posição do coro que Sófocles recomendou através de sua prática e, segundo a tradição, até mesmo por escrito, é o primeiro passo para o aniquilamento do coro, processo cujas fases se sucedem com assustadora rapidez em Eurípides, em Agatão e na Comédia Nova” (NT, \$14). Desse modo, enquanto, em Introdução à tragédia de Sófocles, Nietzsche elege Sófocles como o grande representante da tragédia, em $O$ nascimento da tragédia, Ésquilo ganha esse posto por meio de seu herói Prometeu diante de Édipo: "[...] à glória da passividade contraponho agora a glória da atividade, que o Prometeu de Ésquilo ilumina” (NT, \$9). 
com a Introdução à tragédia de Sófocles $(\$ 10)$, “[...] a tragédia de Eurípides é o termômetro do pensamento estético e ético-político de sua época, em oposição ao desenvolvimento instintivo da arte antiga, que chegou ao seu final com Sófocles". No mesmo período em que anota "[...] minha filosofia, um platonismo invertido" (KSA 7: FP-1870, 7[156]), Nietzsche percebe a antiguidade enquanto um conjunto de forças humanas diversificadas que necessita de leituras complexas. Ou seja, no mesmo período no qual anota para si uma aparente inversão, percebe e expóe uma complexidade muito maior entre os pensadores e os valores da antiguidade. Nesse sentido, apesar das duras críticas a Platão, nunca houve uma cisão plena ou uma mera oposição entre a filosofia platônica e a filosofia nietzschiana.

Com um olhar detido nos testemunhos sobre a biografia do filósofo antigo, $O$ nascimento da tragédia $(\$ 14)$ - que tantas vezes parece soar como um distanciamento pleno do pensamento socrático-platônico - afirma:

Platáo queimou, antes de tudo, os seus poemas, a fim de poder tornarse discípulo de Sócrates. [...] Mas com isso o pensador Platão chegou por um desvio até lá onde, como poeta, sempre se sentira em casa, e onde Sófocles e toda a arte mais antiga protestavam solenemente contra semelhante objeção. Se a tragédia havia absolvido em si todos os gêneros de arte anteriores, cabe dizer o mesmo, por sua vez, do diálogo platônico, o qual nascido, por mistura, de todos os estilos e formas precedentes, paira no meio, entre narrativa, lírica e drama, entre prosa e poesia, e com isso infringe igualmente a severa lei antiga da unidade da forma linguística.

Ou seja, Platão não é visto meramente como um corpo produzido por uma razão instrumental e absurdamente lógica, nem como um corpo produtor simplesmente de tal racionalismo. A filosofia nietzschiana não é também a plena inversáo do platonismo, apesar de algumas de suas anotaçóes pessoais parecerem indicar isso. Mais de uma década depois, Nietzsche (BM, \$204) reflete "[...] até que ponto o nosso mundo moderno se ressente da falta de filósofos tais como Heráclito, Platáo, Empédocles ou qualquer outro nome que tenha tido os sublimes solitários do espírito", enquanto produz, intensifica e dissemina práticas que soterram o cultivo espiritual.

Em outras palavras, o filósofo moderno interpreta Platão como um exemplo positivo diante das atitudes e das ideias que privilegiam a superficialidade intelectual e existencial da modernidade. "Mas de um ponto de vista geral, talvez tenha sido o humano, demasiado humano, isto é, a 
própria mesquinhez dos novos filósofos, o que minou mais radicalmente o respeito pela filosofia [...]” (BM, \$204). No limite, entre tantas críticas ácidas e corrosivas, Além de bem e mal elogia, de certo modo, a postura intelectual de Platão a partir de uma perspectiva bastante específica (a relação entre os filósofos modernos e antigos), porém, bastante importante para a compreensão da crítica nietzschiana ao seu tempo.

Semelhante à atitude platônica diante de seu mestre, Nietzsche (BM, \$190) parece tomar Platão como uma canção popular para lhe arrancar, por meio de cuidadosas apropriaçóes e cirúrgicos recortes, diversidades e multiplicidades próprias. As nuances entre ambos demonstram que a complexidade é maior e mais intensa do que uma mera inversão e representam a variação de ramos filosóficos que ora Nietzsche cultiva, ora Nietzsche poda. Muito mais poderia ser dito sobre essa relação; o que nos importa aqui é, no entanto, apenas evidenciar que as "oposições" nietzschianas nunca são dicotômicas e plenas. Elas não se constituem enquanto uma tensão entre extremidades; elas se constituem enquanto uma tensão entre diversas linhas cuja confusão revela que não existe apenas um centro de força, mas inúmeros centros constantemente se refazendo e se desfazendo conforme as perspectivas que os abarcam. A partir disso, Nietzsche pode afirmar a beleza das inúmeras estrelas que pairam e criam nossa existência.

\section{O CéU dos SÁbios: O SOl de Platão a PARTIR das estrelas de NieTZSCHE}

Em seu prólogo de 1886 para Humano, demasiado Humano, Nietzsche $(\mathrm{HH}$, Prólogo, \$3) nos relata sobre a primeira grande liberação de tudo o que prende e sobrepesa um espírito. $\mathrm{O}$ acontecimento é estrondoso.

A grande liberação, para aqueles atados dessa forma, vem súbita como um tremor de terra: a jovem alma é sacudida, arrebatada, arrancada de um golpe - ela própria não entende o que se passa. Um ímpeto ou impulso a governa e domina; uma vontade, um anseio se agita, de ir adiante, aonde for, a todo custo; uma veemente e perigosa curiosidade por um mundo indescoberto flameja e lhe inflama os sentidos. "Melhor morrer do que viver aqui" - é o que diz a voz e sedução imperiosa: e esse "aqui", esse "em casa" é tudo o que ela amara até então! Um súbito horror e suspeita daquilo que amava, um claráo de desprezo pelo que chamava de "dever", um rebelde, arbitrário, vulcânico anseio de viagem, de exílio, afastamento, esfriamento, enregelamento, sobriedade, um ódio ao amor, talvez um gesto e olhar profanador para trás, para onde até então amava e adorava, talvez um rubor de vergonha pelo que acabava de fazer, e ao mesmo tempo 
uma alegria por fazê-lo, um ébrio, íntimo, alegre tremor, no qual se revela uma vitória - uma vitória? sobre o quê? sobre quem? enigmática, plena de questóes, questionável, mas a primeira vitória - tais coisas ruins e penosas pertencem à história da grande liberação.

Essa vitória contém também os seus perigos e pode fazer com que, ao se livrar de sua primeira "casa", recaia em outras ainda mais perigosas. De qualquer modo, isso é já um estágio posterior a algo. Para afirmar corajosamente: "melhor morrer do que viver aqui!", o espírito deve ter sentido suas correntes como desagradáveis antes de se desprender delas. Significa que, a esse desagrado e a essa grande liberação, precedem paradoxalmente o bemestar, o conforto, a segurança e o medo. Em geral, Nietzsche percebe que os indivíduos da modernidade não almejam libertar-se desse estado, já que, a seu modo, ele lhes agrada; ao contrário, procuram assegurá-lo e intensificálo em suas condições de existência, a fim de garantir um tipo específico de "felicidade". Em outras palavras, eles criam inúmeros mecanismos físicos e psicológicos que canalizam as forças humanas, ao mesmo tempo que inibem quaisquer comportamentos desviantes do ordenamento vigente de sua sociedade. Todavia, existem aqueles que conseguem escapar de tais correntes e, para eles, Nietzsche deixa ainda outro aviso: ao sair de uma prisão, o perigo é entrar em outra. Quando o "espírito livre" se livra da moral que o agarrava, pode acabar criando outras armadilhas morais, as quais, apesar de serem diferentes de seu passado, operam por meio das mesmas estruturas. Somente então o espírito se "liberta" realmente: "[...] basta, o espírito livre sabe agora a qual 'você deve' obedecer, e também do que agora é capaz, o que somente agora lhe é - permitido..." (HH, Prólogo, \$6).

Mais de dois milênios antes, Platão escrevera algo semelhante. No Livro VII de A República, narra sua conhecida alegoria. Platão (2006, 514a-515a) descreve uma caverna onde habitam prisioneiros acorrentados:

Imagina homens que estão numa morada subterrânea, semelhante a uma furna, cujo acesso se faz por uma abertura que abrange toda a extensão da caverna que está voltada para a luz. Lá estão eles, desde a infância, com grilhóes nas pernas e no pescoço de modo que fiquem imóveis onde estáo e só voltem o olhar para a frente, já que os grilhóes os impedem de virar a cabeça. De longe chega-lhes a luz de uma fogueira que arde num local mais alto, atrás deles, e, entre a fogueira e os prisioneiros, há um caminho aclive ao longo do qual se ergue um pequeno muro semelhante ao tabique que os mágicos póem entre eles e os espectadores quando lhes apresentam suas 
habilidades. [...] Imagina homens passando ao longo desse pequeno muro e levando toda espécie de objetos que ultrapassam a altura do muro [...].

Por nunca terem visto nada além daquelas sombras projetadas diante deles, os acorrentados acreditam veementemente em seus olhos. Acostumados a viver naquele estado, os prisioneiros não se veem como tal. Ao contrário, Platão demonstra que a condição deles representa também certo conforto e segurança. Afinal, toda vez que "[...] um deles fosse liberado dos grilhóes e obrigado a pôr-se de pé de repente, a virar o pescoço, a andar e a olhar para a luz, tudo isso o faria sofrer e, sob a luminosidade intensa, ficaria incapaz de olhar para aqueles objetos cujas sombras havia pouco estava vendo" (PLATÃO, 2006, 515c-515d). A libertação de seus grilhóes materiais e intelectuais não seria, portanto, aceitável com tanta facilidade, já que seu corpo e seu pensamento, acostumados com a inércia, não estariam habituados com o movimento filosófico em direção à sabedoria. Diante disso, Platão imagina que, caso algum deles se soltasse, perceberia a realidade fora da caverna com muito esforço físico e intelectual; e, após intensa contemplação da nova paisagem, sentiria a necessidade de retornar para sua antiga moradia, a fim de avisar seus companheiros. Mas, “[...] a quem tentasse libertá-los e conduzi-los lá para cima, se de alguma forma pudessem segurá-lo com suas mãos e matálo, eles não o matariam?” (PLATÃO, 2006, 517a).

A alegoria da caverna simboliza tanto a epistemologia quanto a política de Platão. Ao retornar, o liberto evidencia a impossibilidade de dissociar a filosofia da política. A fim de modificar as estruturas de sua antiga sociedade em prol da sabedoria, ameaça o conforto e a segurança dos acorrentados, os quais, por sua vez, ameaçam o ex-prisioneiro - em clara referência à vida e à condenaçáo de Sócrates e ao destino inevitável de todo filósofo. Tudo nessa alegoria representa algo em nossa realidade, "[...] assemelhando o lugar que vemos com nossos olhos à morada na prisão, e a luz da fogueira que arde lá ao poder do sol" (PLATÃO, 2006, 517b). O desacorrentar-se, o andar, as cegueiras momentâneas do liberto e sua volta representam o movimento de reflexão do sábio. "E se tomares a subida até o alto e a visão das coisas que lá estão como a ascensão da alma até o mundo inteligível, não me frustrarás em minha expectativa, já que queres ouvir-me falar dela" (PLATÃO, 2006, 517b).

Todavia, nessa alegoria, o sol não se equaliza ao nosso, como uma interpretação descuidada poderia acreditar. Ele simboliza algo maior: a Verdade e o Bem: "[...] quando, já engajados no caminho dialético, nos 
tornamos para as sendas batidas, que experimentamos como uma ofuscação diante da obscuridade, uma impressão de despertar após um sonho profundo" (GOLDSCHMIDT, 1970, p. 34). O sol de Platão é o grau máximo da verdade que, em vida, podemos apenas contemplar com certa dificuldade; mas que, ao ser visto, nos permite perceber o plano sensível que nos cerca e sair da condiçãao de prisioneiros que nascemos.

No mundo cognoscível, vem por último a ideia do bem que se deixa ver com dificuldade, mas, se é vista, impóe-se a conclusão de que para todos é a causa de tudo quanto é reto e belo e que, no mundo visível, é ela quem gera a luz e o senhor da luz e, no mundo inteligível, é ela mesma que, como senhora, propicia verdade e inteligência, devendo tê-la diante dos olhos quem quiser agir com sabedoria na vida privada e pública (PLATÃO, 2006, 517c)

O prólogo de Humano, demasiado humano ecoa com essa alegoria platônica - para náo falarmos dos movimentos constantes de Zaratustra entre o exílio e a solidão em sua caverna e a barulhenta e atormentada sociedade. Aqui, pontual e sutilmente, Nietzsche conversa com o filósofo antigo, demonstrando a precisão e a maleabilidade do perspectivismo. A aproximação ao prisioneiro platônico é realizada, nesse caso, com o objetivo paradoxal de se distanciar dos desfechos metafísicos do platonismo, pois as alegorias nietzschianas também são outras: querem-se múltiplas de sentidos. Para Platão, o sol representa a Verdade e o Bem suprassensíveis; para Nietzsche, ele significa, na alegoria platônica, um modelo dogmático que, inclusive, não se reconhece como tal. De acordo com Tongeren (2012, p. 124), “[...] o único sol cintilante e brilhante acaba atraindo para si toda atençáo, ao passo que inúmeros corpos celestes escuros permanecem invisíveis ao lado do sol". Mais do que a verdade, a metáfora de Platão esconde inúmeros outros astros, como o dia que vela um céu poeticamente estrelado, mas que se revela durante a noite: "[...] há inúmeros corpos escuros ao lado do Sol a serem explorados alguns que nunca veremos” (BM, \$196).

Quebrar suas correntes e sair da caverna são processos filosóficos que ultrapassam o reconhecimento de uma única estrela, já que contemplam o céu durante o dia e durante a noite. Nietzsche se esforça em demonstrar que a imensidão de possibilidades é solapada por valores que se esforçam em escondêla, afinal, "[...] a luz das estrelas mais distantes é a última a chegar aos homens; e enquanto ela não chega, os homens negam que ali - haja estrelas" (BM, \$285). Para o filósofo, são elas e suas inúmeras constelaçóes que representam 
a ambiguidade à qual os seres humanos modernos estão submetidos: eles se encontram sob uma diversidade de valores e culturas constantemente ocultada e difamada por morais autoritárias e dominantes de seu tempo.

Assim como no reino das estrelas são às vezes dois sóis que determinam a órbita de um planeta, e em alguns casos há sóis de cor diversa que iluminam um só planeta, ora com luz vermelha, ora com luz verde, logo irradiando simultaneamente e inundando-o de luz multicor: assim também nós, homens modernos, graças à complicada mecânica de nosso "firmamento" somos determinados por morais diversas; nossas açóes brilham alternadamente em cores distintas, raras vezes são inequívocas - e com frequência realizamos açóes furta-cor (BM, \$215)

A história mesma desse dogmatismo é antiquíssima: provém de confrontos rudes, argumentaçóes ardilosas, fisiologias dominantes - até culminar em uma Europa moderna que se almeja como um grande rebanho, constante e previsível, mas que se quer universal e eterna. O cogito de Descartes, os axiomas de Espinosa, os juízos a priori de Kant, o bem-estar e a felicidade do utilitarismo e liberalismo compóem e consumam, concomitantes a tantos outros conceitos, as relaçôes de poder da modernidade. No limite, o poder é conceitual, ou melhor, moral - o que faz dos pensadores os grandes governantes de seu tempo. Pôr-se contra Descartes e Kant é, nesse sentido, problematizar a moral das civilizaçóes europeias.

Talvez o problema se inicie quando uma determinada moral resolve negar justamente o jogo da vontade de poder que está presente na emergência das mais diversas morais e que permeia as relaçóes entre elas. Essa moral se apresenta então não como uma moral, mas como "a" moral, colocandose acima de seu próprio palco de emergência para poder se impor como moral dominante e controlar as regras do jogo, podendo fazê-lo parar quando the aprouver (PASCHOAL, 2009, p. 32)

São, portanto, fundamentais as perguntas que Nietzsche $(B M, \$ 1)$ nos faz: "Quem, realmente, nos póe questóes? O que, em nós, aspira realmente à verdade'? [...] Certo, queremos a verdade: mas por que não, de preferência, a inverdade? Ou a incerteza? Ou mesmo a insciência?" Cogitar o comumente incogitável apresenta-se como uma radical atitude contrária a todo dogmatismo - mesmo aquele que se refugia nos recônditos da filosofia. Afinal, o que há para além de nosso sol? Criticar as estruturas da verdade é evidenciar os operadores que organizam nossa sociedade e, consequentemente, consumar 
uma análise política que subverte os mecanismos dogmáticos da moral. Nesse sentido, o objetivo do confronto nietzschiano contra o cristianismo, como religião universal, se mostra por exemplo: "Eu declarei guerra aos anêmicos 'ideais-cristãos' (junto ao que lhe é intimamente aparentado), não com o objetivo de aniquilá-lo, senão apenas para pôr um fim à sua tirania e arranjar um lugar livre para novos ideais, para ideais mais robustos..." (KSA 12: FP1887, 10[117]). Nietzsche toma cuidado com o fanatismo. O fanático opera por meio da eliminação de seus adversários; somente desse modo, consegue se impor como único e verdadeiro.

O fanatismo utiliza diversos instrumentos e estratégias a fim de estabelecer e manter sua ordem. "A consciência, a boa reputação, o inferno, às vezes até a polícia não permitiam e não permitem a imparcialidade; na presença da moral, como diante de toda autoridade, não se deve pensar, menos ainda falar: aí - se obedece” (A, Prefácio, \$3). Ora, se a atmosfera da modernidade coage-nos a determinados modos de vida e determinados valores, resistir contra a gravidade de suas imposiçôes é tanto uma demonstração de força quanto um engajamento a favor da afirmação e exaltação da pluralidade humana (PASCHOAL, 1999, p. 109). A filosofia nietzschiana é tanto um reduto contra autoritarismos quanto uma arma e uma estratégia de ataque contra eles. Quando um valor se quer dominante, corre o risco de se tornar também ignorante - mesmo que sua característica inicial fosse a sabedoria e a crítica. Nesse sentido, Nietzsche identifica uma estrutura autoritária na filosofia de Platão que, aqui, percebemos por meio sua alegoria e sua correlação entre o sol e a verdade. A filosofia nietzschiana pensa, assim, a diversidades dos astros celestes como símbolos para as inúmeras perspectivas morais existentes.

\section{Consideraçótes Finais}

O prólogo da segunda edição de Humano, demasiado humano concentra, em sua forma e em seu conteúdo, uma relação direta com a filosofia platônica. Em certos momentos, descreve fielmente a alegoria da caverna platônica como se fosse partidário dela. Em outros, torna-se uma visão crítica ao saber de Platão. Ao quebrar suas correntes e fugir de sua antiga morada, o prisioneiro nietzschiano tenha se deparado, talvez, com a noite. De qualquer modo, ele parece assumir um movimento constante: de sua caverna para fora; de fora, para dentro. Talvez, a sociedade seja exatamente o "fora" da prisão para Nietzsche. Náo à toa, "[...] aos trinta anos de idade, Zaratustra deixou sua pátria e o lago 
de sua pátria e foi para as montanhas. Ali gozou do seu espírito de sua solidão, e durante dez anos não se cansou" (ZA, Prólogo, \$1). Mas, diferente do prisioneiro platônico, a mudança de contexto da personagem persa acontece inúmeras vezes, abrindo, inclusive o livro: "Ó grande astro! Que seria de tua felicidade, se não tivesses aqueles que iluminas? [...] Zaratustra desceu sozinho pela montanha, sem deparar com ninguém” (ZA, Prólogo, \$1-\$2). Próximo e distante, paradoxalmente, a Sócrates, a Jesus e a Zoroastro, Zaratustra dirigese ora à sociedade, ora à sua caverna e solidão, como se refletisse e depurasse cada novo conhecimento, a ponto de nos induzir à seguinte pergunta: e se as verdades platônicas se transformaram em correntes?

Afinal, Platão não elucida, em sua alegoria, que as pôs primeiramente. E se foram os prisioneiros que, querendo-se na condição de escravos, forjaram suas algemas? E se suas convicções foram criadas, talvez, por algum outro prisioneiro que se soltara tempos atrás e lhes trouxera a "verdade", a qual, por sua vez, se consolidara em tradiçáo? E se, talvez, para se precaverem exatamente da sedução da verdade, tivessem inventado outra, ainda mais dura e cruel? Enfim, e se, talvez, tais correntes foram feitas por alguém que se soltara anteriormente e, em vez de assumir uma postura socrática - que mais contesta a verdade do que a assume como um dogma -, aprisionou seus amigos e parentes para exercer seu poder sobre eles? "Mas quem se mostra disposto a ocupar-se de tais perigosos 'talvezes'?” (BM, \$2). A filosofia nietzschiana exalta a libertação das correntes e o cuidado para que determinados valores não se se contradigam e se queiram universais e autoritários. Nesse sentido, as perguntas se tornam poderosas estratégias de genealogia, de interpretação e de subversão. Com elas, conseguimos cogitar contextos e perspectivas diferentes, as quais, mesmo se forem inverídicas, nos abrem o horizonte da dúvida e ganham uma importância única (note-se, aqui, o distanciamento entre Platão e Nietzsche). Esse horizonte é, por sua vez, difícil de ser suportado, pois estamos habituados ao que é "tradicional", "certo" e "seguro" (observe-se, aqui, a aproximação entre Platáo e Nietzsche).

Por isso, a diversidade se torna um "perigo" para toda a verdade que se quer universal e eterna e para todo o conhecimento solidificado que não admite o que dele diverge. Em outras palavras, a dúvida se relaciona com um tipo de organismo peculiar semelhante à verdade platônica - que requer também constituiçôes fisiológicas específicas. Cada um possui olhos diferentes e, por conseguinte, enxerga paisagens e belezas variadas. Quando Nietzsche percebe a diversidade dos astros celestiais, ele permite, a si, o desconhecido 
e, quiçá, o impossível. Aceita, antes de tudo, a possibilidade do "diferente"; ou seja, daquilo que, fugindo aos padróes e às "normalidades", cogita novas formas de viver e de experimentar; espera "[...] o advento de uma nova espécie de filósofos, que tenham gosto e pendor diversos, contrários aos daqueles que até agora existiram - filósofos do perigoso 'talvez' a todo custo” (BM, \$2) - e que já os percebe surgindo.

Olhar os astros celestes retoma uma atitude antiga presente na história da filosofia. "Um dia, em que lhe perguntaram por que tinha nascido, Anaxágoras respondeu: 'Para observar o sol, a lua e o céu' - Eis aí a resposta de um sábio" (GOLDSCHMIDT, 1970, p. 19). Tanto em Platão quanto em Nietzsche, esse gesto se mantém. Ambos, como tantos outros pensadores, transformaram-no em uma alegoria que expressa complexas visóes filosóficas; mas esse último quer ver a diversidade de estrelas (e, aqui, poderíamos substituí-las por "valores") e perceber suas mais sutis características. O céu de Nietzsche tenta abarcar os astros, e não excluí-los; ou, ao menos, tenta náo impedir, por meio de elaborados argumentos, que eles existam. Isso gera, também, um movimento que oscila entre o distanciamento e a aproximação à filosofia platônica. Seja direcionada a Platão ou ao cristianismo, a filosofia nietzschiana não pretende a aniquilação de seus divergentes. Também não se reduz a meras inversóes e oposiçóes radicais, sem pontos de aproximação. $\mathrm{O}$ céu nietzschiano é estrelado: o que inclui todo tipo de sol e o que compóe, desse modo, uma incrível variedade de valores e complexidades cuja sabedoria ilumina, por diferentes cores e ângulos, novas constelaçóes, possibilitando, enfim, o surgimento de "tantas auroras que ainda não brilharam" (A, mote).

SABATINI, M. The sky of the wise: Plato's sun from the Nietzsche's stars. Trans/form/ação, Marília, v. 44, n. 2, p. 233-250, Abr./Jun, 2021.

\footnotetext{
Abstract: Many thinkers have reflected on the celestial stars. With Plato and Nietzsche, they assume an allegorical position closely related to their philosophies. In The Republic, the sun represents the truth, on the one hand, becoming the symbol that drives the wise in their quest for knowledge; on the other hand, it also represents important aspects of the political and epistemological theory of Platonic philosophy. Millennia later, Nietzsche criticizes intensely Plato, diagnosing dogmatic aspects in their thinking. Against this, the Nietzschean stars assume a diverse sky, whose stars represent an incredible moral variety existing among human beings. But the modern philosopher does not oppose the Platonic
} 
philosophy simply and fully. By this we intend to demonstrate that Plato's sun and Nietzschean stars serve as allegories to synthesize fundamental points in the philosophical conception of such thinkers; but they also help us to highlight the complexity of Nietzsche's interpretation of Platonic philosophy.

Keywords: Truth. Dogmatism. Politics. Moral. Diversity.

\section{Bibliografia}

ANDLER, C. Nietzsche, sa vie et sa penséé: Les Précurseurs de Nietzsche. Paris: Bossard, 1920.

ANDLER, C. Nietzsche, sa vie et sa penséé: La Jeunesse de Nietzsche. Paris: Bossard, 1921a.

ANDLER, C. Nietzsche, sa vie et sa penséé: Le Pessimisme Esthétique de Nietzsche. Paris: Bossard, 1921b.

ANDLER, C. Nietzsche, sa vie et sa penséé: Nietzsche et transformisme intellectualiste. Paris: Bossard, 1922.

ANDLER, C. Nietzsche, sa vie et sa penséé: La maturité de Nietzsche. Paris: Bossard, 1928.

ANDLER, C. Nietzsche, sa vie et sa penséé: La dernière philosophie de Nietzsche. Paris: Bossard, 1931.

DANTE, A. A divina comédia - Inferno. Trad. de Italo Eugenio Mauro. São Paulo: Editora 34, 1998.

DIELS, H. Poetarum Philosophorum Fragmenta. Berolini: Hermannus Diels, 1901.

FINK, E. La philosophie de Nietzsche. Trad. de Hans Hildenberg e Alex Lindenberg. Paris: Les Éditions de Minuit, 1965.

GOLDSCHMIDT, V. A religiáo de Platão. Trad. de Ieda e Oswaldo Porchat. São Paulo: Difusão Europeia do Livro, 1970.

HESÍODO. Teogonia: a origem dos deuses. Trad. de Jaa Torrano. São Paulo: Iluminuras, 2011.

JANZ, C. P. Friedrich Nietzsche: uma bibliografia (Volume I: infância, juventude, anos em Basileia). Trad. de Markus A. Hediger. Petrópolis: Vozes, 2016a.

JANZ, C. P. Friedrich Nietzsche: uma bibliografia (Volume II: os dez anos do filósofo livre). Trad. de Markus A. Hediger. Petrópolis: Vozes, 2016b.

JANZ, C. P. Friedrich Nietzsche: uma bibliografia (Volume III: os anos de esmorecimento, documentos, fontes e registros). Trad. de Markus A. Hediger. Petrópolis: Vozes, 2016c. 
LAÊRTIOS, D. Vidas e doutrinas dos filósofos ilustres. Trad. de Mário da Gama. Brasília: Editora Universidade de Brasília, 2008.

LÖWITH, K. Nietzsche: philosophie de l'éternel retour du même. Trad. de Anne-Sophie Astrup. Paris: Calmann-Lévy, 1991.

NIETZSCHE, F. Sämtliche Werke. Kritische Studienausgabe. G. Colli und M. Montinari (Hg). Berlin: Walter de Gruyter, 1999. 15 Bd.

NIETZSCHE, F. Aurora. Trad. de Paulo César de Souza. São Paulo: Companhia das Letras, 2004.

NIETZSCHE, F. Além do bem e do mal. Trad. de Paulo César de Souza. São Paulo: Companhia das Letras, 2005a.

NIETZSCHE, F. Humano, demasiado humano. Trad. de Paulo César de Souza. São Paulo: Companhia das Letras, 2005b.

NIETZSCHE, F. Crepúsculo dos Ídolos. Trad. de Paulo César de Souza. São Paulo: Companhia das Letras, 2006a.

NIETZSCHE, F. Introduçáo à tragédia de Sófocles. Trad. de Ernani Chaves. Rio de Janeiro: Jorge Zahar, 2006b.

NIETZSCHE, F. Sócrates y la tragedia. In: NIETZSCHE, F. El nacimiento de la tragedia. Trad. de Andrés Sánches Pascual. Madrid: Alianza, 2007a.

NIETZSCHE, F. O nascimento da tragédia. Trad. de J. Guinsburg. São Paulo: Companhia das Letras, $2007 \mathrm{~b}$.

NIETZSCHE, F. Assim falou Zaratustra. Trad. de Paulo César de Souza. São Paulo: Companhia das Letras, 2011.

PASCHOAL, A. E. A dinâmica da vontade de poder como proposiçáo moral nos escritos de Nietzsche. 1999. Tese (Doutorado) - Unicamp, Campinas, 1999.

PASCHOAL, A. E. Nietzsche e a auto-superação da moral. Ijuí: Ed. Unijuí, 2009.

PLATÃO. Defesa de Sócrates. Trad. de Jaime Bruna. São Paulo: Abril Cultural, 1972a (Coleção Os Pensadores).

PLATÃO. Sofista. Trad. de Jorge Paleikat e João Cruz Costa. São Paulo: Abril Cultural, 1972b (Coleção Os Pensadores).

PLATÃO. Íon. Trad. de Victor Jabouille. Lisboa: Inquérito, 1988.

PLATÃO. Crátilo. Trad. de Carlos Alberto Nunes. Belém: Ed. UFPA, 2001a.

PLATÃO. Mênon. Trad. de Maura Iglésias. Rio de Janeiro: Ed. PUC-Rio; Loyola, 2001b. PLATÃO. Protágoras. Trad. de Carlos Alberto Nunes. Belém: Ed. UFPA, 2002.

PLATÃO. A República. Trad. de Anna Lia Amaral de Almeida Prado. São Paulo: Martins Fontes, 2006. 
PLATÃO. Fédon. Trad. de Carlos Alberto Nunes. Belém: Ed. UFPA, 2011 a.

PLATÃO. Fédro. Trad. de Carlos Alberto Nunes. Belém: Ed. UFPA, 2011 b.

PLATÃO. Teeteto. Trad. de Adriana Manuela Nogueira e Marcelo Boeri. Lisboa: Calouste Gulbenkian, 2015.

TONGEREN, P. van. A moral da crítica de Nietzsche à moral: estudo sobre Para além do bem e do mal. Trad. de Jorge Viesenteiner. Curitiba: Champagnat, 2012.

WOTLING, P. Nietzsche e o problema da civilizaçáo. Trad. de Vinicius de Andrade. São Paulo: Barcarolla, 2013. 